\title{
10. SITE 455: EAST SIDE OF THE MARIANA TROUGH ${ }^{1}$
}

\author{
Shipboard Scientific Party ${ }^{2}$
}

\section{SITE 455}

Date occupied: 10 April 1978

Date departed: 11 April 1978

Time on hole: 31.0 hours

Position: $17^{\circ} 51.26^{\prime} \mathrm{N} ; 145^{\circ} 21.48^{\prime} \mathrm{E}$

Water depth (sea level; corrected m, echo-sounding): 3465

Water depth (rig floor; corrected m, echo-sounding): 3475

Bottom felt (m, drill pipe): 3478

Penetration (m): 104

Number of holes: 1

Number of cores: 11

Total length of cored section (m): 104.0

Total core recovered $(\mathrm{m}): 31.28$

Core recovery $(\%): 30.0$

Oldest sediment cored:

Depth sub-bottom (m): 104

Nature: vitric sand ash mudstone

Age: early Pleistocene (0.9-1.6 m.y.)

Measured velocity $(\mathrm{km} / \mathrm{s}): 1.59^{3}$

Basement:

Depth sub-bottom $(\mathrm{m})$ : not reached

Principal results: Site 455 (SP-4D) is $54 \mathrm{~km}$ east of the suspected Mariana Trough spreading axis, near a bathymetric high rising above the volcanogenic sediment apron from the active Mariana volcanic arc. The apron thins from the east from over $1 \mathrm{~km}$ thick to about $300 \mathrm{~km}$ thick at the site. Volcanic basement at Site 455 should have an age intermediate between that at Site 453 (SP-4F) and Site 454 (SP-4E) to the west, if spreading has been fairly symmetric.

Total penetration was 104 meters with a 30 per cent recovery rate. The upper 22 meters comprises vitric mud with sandy ash layers. Vitric nannofossil oozes are also present in some bands. From 22 to 95 meters, volcanic sand and gravel with minor nannofossil mud and silty tuff were cored. Volcaniclastic material includes angular basalt grains, bits of basalt-glass and pumice fragments, probably from the nearby Pagan and Alamagan Islands. Below 95 meters sub-bottom, recovery consisted of only two

\footnotetext{
1 Initial Reports of the Deep Sea Drilling Project, Volume 60.

2 Donald M. Hussong (Co-Chief Scientist), Hawaii Institute of Geophysics, Honolulu, Hawaii; Seiya Uyeda (Co-Chief Scientist), Earthquake Research Institute, University of Tokyo, Tokyo, Japan; René Blanchet, Université de Bretagne Occidentale, Brest, France; Ulrich Bleil, Institut für Geophysik, Ruhr Universität, Bochum, Federal Republic of Germany; C. Howard Ellis, Marathon Oil Company, Denver Research Center, Littleton, Colorado; Timothy J. G. Francis, Institute of Oceanographic Sciences, Surrey, United Kingdom; Patricia Fryer, Hawaii Institute of Geophysics, Honolulu, Hawaii; Ki-Iti Horai, LamontDoherty Geological Observatory, Palisades, New York: Stanley Kling, Marine Life Research Group, Scripps Institution of Oceanography, La Jolla, California (present address: 416 Shore View Lane, Leucadia, California); Arend Meijer, Department of Geosciences, University of Arizona, Tucson, Tokyo, Tokyo, Tokyo, Tokyo, Japan; James H. Natland, Deep Sea Drilling Project, Scripps Institution of Oceanography, La Jolla, California; Gordon H. Packham, Department of Geology and Geophysics, University of Sydney, Sydney, N.S.W. Australia; and Anatoly Sharaskin, Vernadsky Institute of Geochemistry, U.S.S.R. Academy of Sciences, Moscow, U.S.S.R.

${ }^{3}$ Velocity of vitric mud from approximately 21 meters sub-bottom.
}

pieces of pale olive sediment. The upper piece is burrowed vitric mudstone and the lower piece is graded bedded tuff overlain by laminated and cross-laminated vitric mudstone. These lithologies resemble the graded bedded sequences from the early Pliocene at Site 453 and the early Pleistocene at Site 454 . The oldest sediment at Site 455 can be referred to the early Pleistocene Emiliania annula Subzone. The hole was abandoned with no downhole logging, because of massive caving of the sand into the hole. The ship was subsequently moved to Site 456 , about $17 \mathrm{~km}$ west of Site 455 , in a second attempt to meet the SP-4D objectives.

\section{BACKGROUND AND OBJECTIVES}

The easternmost Mariana Trough drilling target (Fig. 1), designated SP-4D for site selection purposes, was planned as an attempt to sample back-arc basin crust that is of intermediate age between the youngest (Site 454; SP-4E) and oldest (Site 453; SP-4F) available drill sites. For a description of the overall objectives of the South Philippine Sea drilling in general, and the Mariana Trough in particular, see the Background and $\mathrm{Ob}-$ jectives chapter for the Mariana Trough.

Site 455 was selected to be on the eastern ridge of the possible axis of crustal extension in the Trough in order to serve as a check on spreading symmetry as well as to help define the rate of back-arc spreading.

In addition to basin spreading history, we hoped that the sediments at the site, which are part of the thick apron of volcanogenic material from the active volcanic arc, would contain a record of the past few million years of arc volcanic activity. The location of SP-4D was, therefore, as far east of the Mariana Trough axis as it

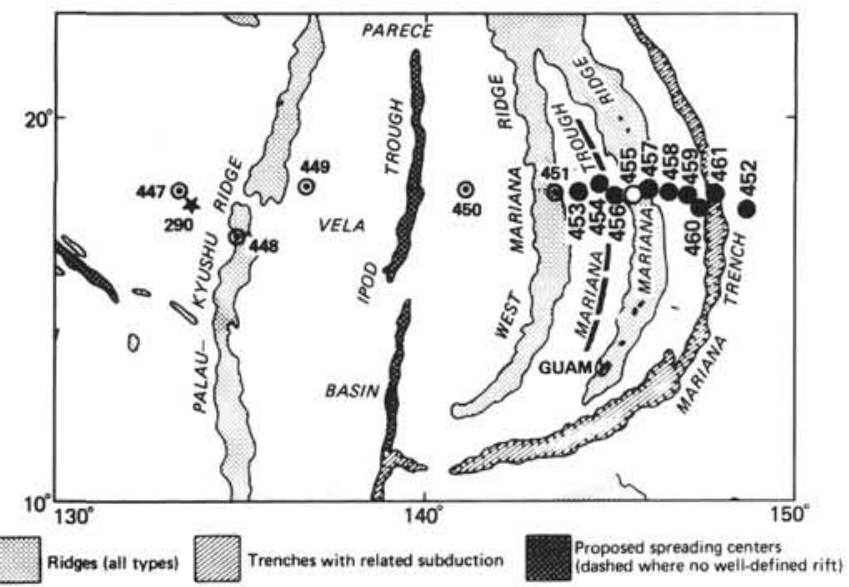

Figure 1. Location of Site 455 (open circle) and other Leg 60 drill sites (closed circles), as well as Leg 59 sites (crosses) in the South Philippine Sea transect. 
could be and still have a sediment cover that was possible to penetrate to basement. Unfortunately, the site survey showed that, toward the east, the sediments rapidly become too thick for drilling, so the chosen drill site had to be near the side of a bathymetric high against which the sediments pinch out (Fig. 2).

We also anticipated that the igneous rocks to be sampled in basement at SP-4D were formed at the Mariana Trough spreading center. If so, they would be only slightly older than the material sampled at Site 454 . The SP-4D rocks, however, would have been covered by the thick apron of volcanogenic sediments very soon after formation, whereas the Site 454 rocks would have had only sparse sediment cover for most of their existence. The basement at Site 455 may therefore have experienced a different type and degree of hydrothermal alteration than basement at Sites 454 and 456 .

\section{OPERATIONS}

The target area for Site 455 was known from site survey data to be covered by very thick $(>1 \mathrm{~km})$ sediments, so several hours of Challenger profiling time were devoted to locating a place where these sediments pinched out against a basement high. The objectives of the drilling were both to sample basement crustal rocks and to obtain a sediment section that would include the maximum possible history of recent volcanic activity. The profiling was accomplished with the standard geophysical profiling system, including $3.5-\mathrm{kHz}$ and 12 $\mathrm{kHz}$ precision bathymetry, an 120 -cu. in. air-gun with a single-channel hydrophone array, and magnetometer.

An appropriate site was located, and a $13.5-\mathrm{kHz}$ double-life beacon was dropped at 1230 local time on 10 April 1978. Sediment thickness was over 300 meters, so the full bottom-hole assembly with a standard F93CK bit was rigged. Water depth from the PDR was calculated to be 3465 corrected meters. The pipe was run and spudded in at 2245 local time at 3478 meters (depth below rig floor, so the length of pipe below sea level was 3468 meters).

The coring summary is listed in Table 1, and the coring rates for each core are shown on Figure 3. Coarse volcanic sand was brought up in the first core and was encountered in all subsequent cores.

The Uyeda/Kinoshita heat probe was to have been run after Core 10, at a sub-bottom depth of 94.5 meters. While making preparations for this measurement, however, the hole caved in around the drill pipe, causing the latter to be stuck temporarily. The heat flow measurement attempt was postponed. During the cutting of Core 11 , torquing and sticking increased dramatically, apparently the result of massive caving of the sands into the hole. This forced the abandonment of the hole.

At 1250 local time on 11 April, the bit was pulled from the hole. The drill string was aboard and secured at 1956 local time.

\section{LITHOLOGY OF SEDIMENTS}

At Site 455, 104 meters of sediments were cored, with 31.28 meters recovered. Three lithological units may be distinguished (Fig. 4).

Unit I: Mud, ooze, and ash, late Pleistocene; Core 1 to Core 3, Section 2, $110 \mathrm{~cm}, 0$ to 22 meters sub-bottom.

The sediments are moderate yellowish brown, vitric muds with dusky yellowish brown, sandy ash layers. Vitric nannofossil oozes with up to 50 per cent of nannofossils are present in some bands. Foraminifers occasionally reach 10 per cent (Core 1 , Section 6; Core 2, Section 4), when they are visible in the core.

Volcanic glass constitutes 5 to 70 per cent of the 15 samples examined in smear slides. The most common type is pale brown in color and shows various degrees of alteration. In addition, there is abundant clear glass with tiny pipe-vesicles and a refractive index lower than

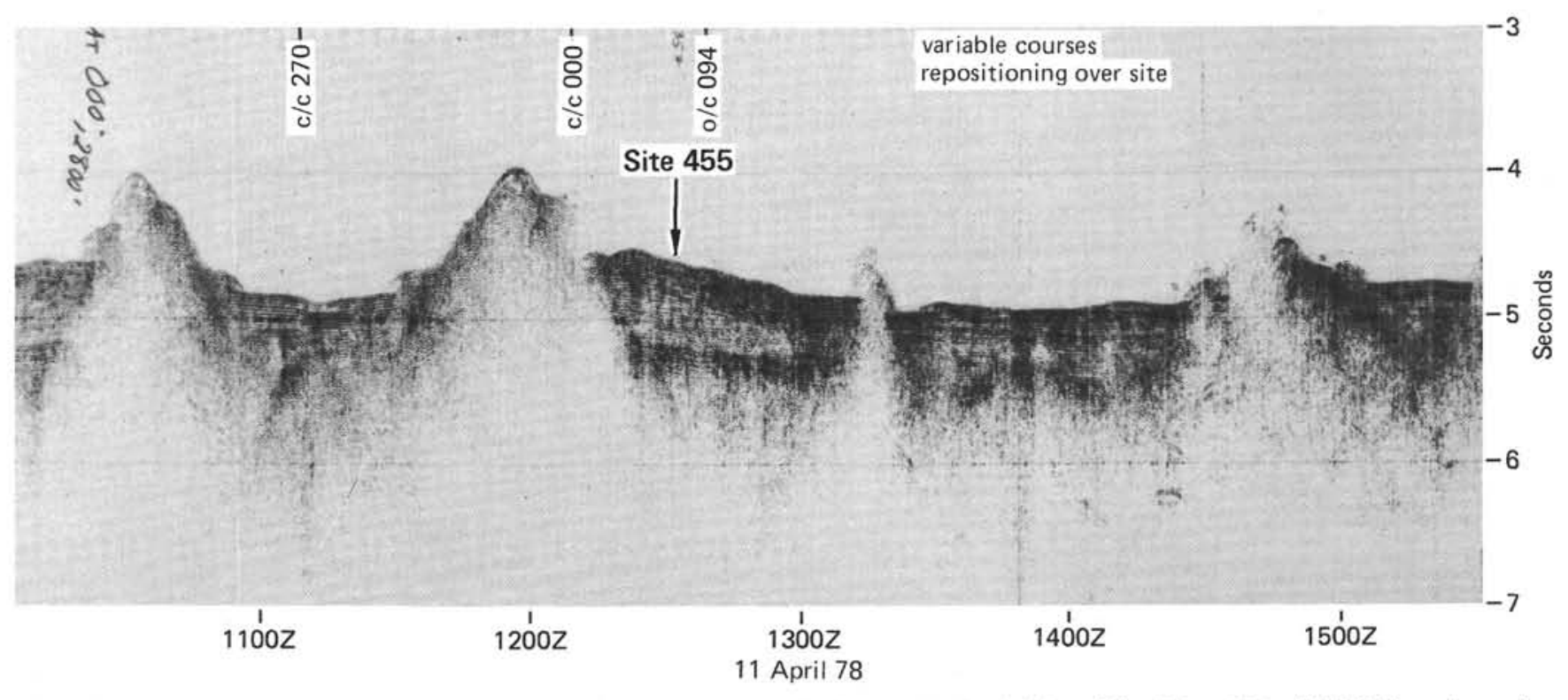

Figure 2. Portion of Glomar Challenger air-gun profiler record during pre-site survey in the vicinity of Site 455 on 10 April 1978 . Several crossings of the same basement outcrop are shown, with turbiditic sediments of the western Mariana arc apron banked against it. 
Table 1. Coring summary, Site 455.

\begin{tabular}{|c|c|c|c|c|c|c|c|}
\hline Core & $\begin{array}{c}\text { Date } \\
\text { (April } \\
1978 \text { ) }\end{array}$ & Time & $\begin{array}{l}\text { Depth from } \\
\text { Drill Floor } \\
\text { (m) }\end{array}$ & $\begin{array}{l}\text { Depth below } \\
\text { Sea Floor } \\
\text { (m) }\end{array}$ & $\begin{array}{l}\text { Length } \\
\text { Cored } \\
\text { (m) }\end{array}$ & $\begin{array}{l}\text { Length } \\
\text { Recovered } \\
\text { (m) }\end{array}$ & $\begin{array}{c}\text { Recovery } \\
(\%)\end{array}$ \\
\hline 1 & 10 & 2331 & $3478.0-3487.0$ & $0-9.0$ & 9.0 & 8.62 & 95.8 \\
\hline 2 & 11 & 0052 & $3487.0-3496.5$ & $9.0-18.5$ & 9.5 & 9.14 & 96.2 \\
\hline 3 & 11 & 0221 & $3496.5-3506.0$ & $18.5-28.0$ & 9.5 & 5.16 & 54.3 \\
\hline 4 & 11 & 0340 & $3506.0-3515.5$ & $28.0-37.5$ & 9.5 & 0.07 & 0.7 \\
\hline 5 & 11 & 0441 & $3515.5-3525.0$ & $37.5-47.0$ & 9.5 & 2.37 & 24.9 \\
\hline 6 & 11 & 0547 & $3525.0-3534.5$ & $47.0-56.5$ & 9.5 & 0.12 & 1.3 \\
\hline 7 & ii & 0707 & $3534.5-3544.0$ & $56.5-66.0$ & 9.5 & 1.71 & 18.0 \\
\hline 8 & 11 & 0812 & $3544.0-3553.5$ & $66.0-75.5$ & 9.5 & 0.02 & 0.2 \\
\hline 9 & 11 & 0935 & $3553.5-3563.0$ & $75.5-85.0$ & 9.5 & 0.10 & 1.1 \\
\hline 10 & 11 & 1105 & $3563.0-3572.5$ & $85.0-94.5$ & 9.5 & 3.87 & 40.7 \\
\hline 11 & 11 & 1243 & $3572.5-3582.0$ & $94.5-104.0$ & 9.5 & 0.10 & 1.1 \\
\hline Total & & & & & 104.0 & 31.28 & 30.0 \\
\hline
\end{tabular}

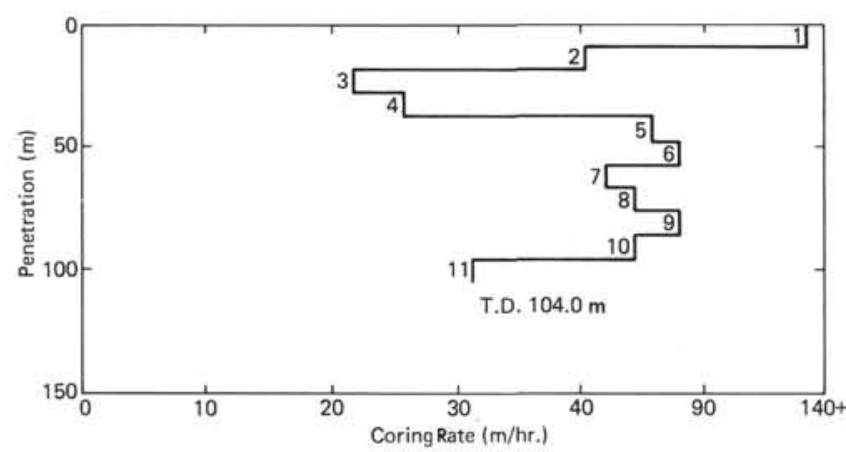

Figure 3. Coring rates for each core, Site 455 , in meters per hour. T.D. = total depth. Core numbers are shown on the figure.

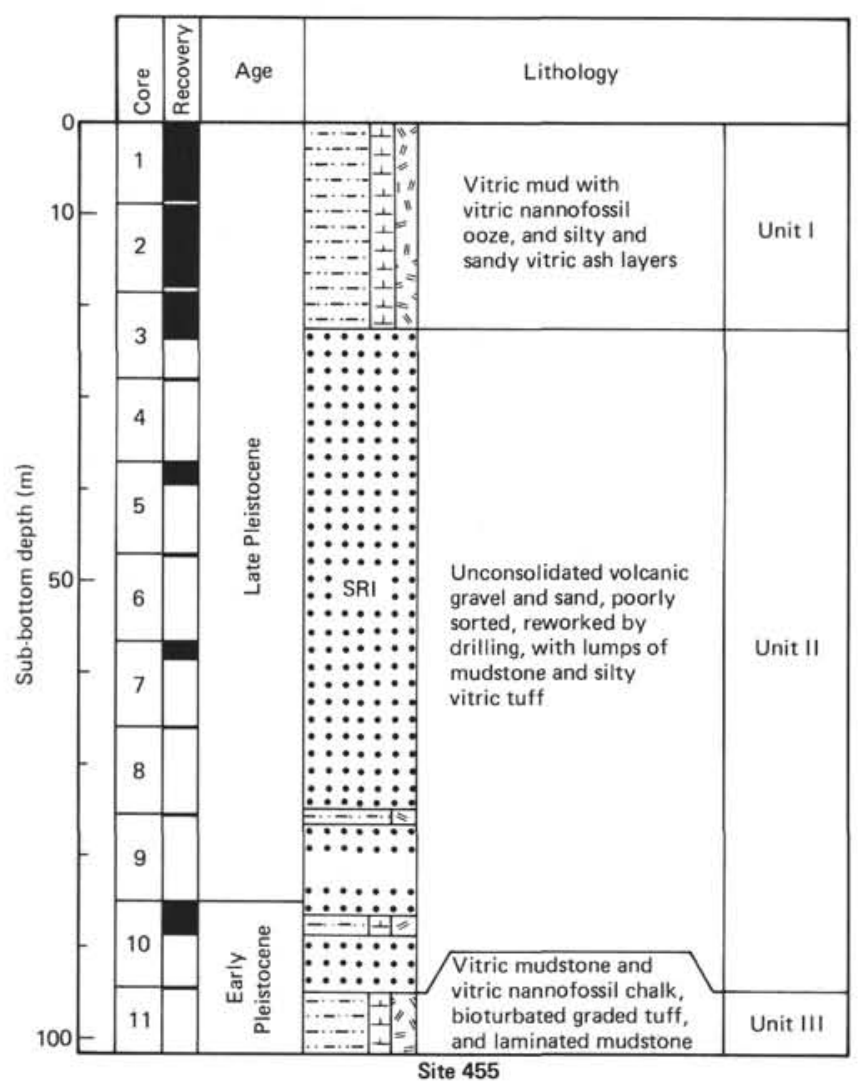

Figure 4. Lithologic column and summary lithology, Site 455. balsam in the vitric nannofossil ooze of Core 3, Section $2,72 \mathrm{~cm}$.

Unit II: Coarse ash, early to late Pleistocene; Core 3, Section $2,110 \mathrm{~cm}$ to Core $11 ; 22$ to 95 meters subbottom.

Mainly unconsolidated volcanic sand and gravel were recovered from this unit together with minor nannofossil mud and silty tuff. The recovery was only 19.9 per cent.

The volcanic sand and gravel are moderately to poorly sorted; both the structures and textures of the recovered sediment are largely attributable to drilling disturbance. For example, in Core 5 coarser and lighter pumice grains were hydraulically concentrated in the center of the core liner giving a vertical coarse band along the core axis. In Cores 3 (Section 2, 59 to $77 \mathrm{~cm}$; Section 2, $120 \mathrm{~cm}$ to Section 3, $51 \mathrm{~cm}$; and Section 3, 77 $\mathrm{cm}$ to Section 4, $28 \mathrm{~cm}$ ) and 10 (Section $1,10 \mathrm{~cm}$ to Section $3,85 \mathrm{~cm}$ ) paler pumice grains are concentrated in the upper part of the beds. The pumice grains also increase in size upward. The sand and gravel are olivegray and dominantly composed of poorly vesicular brownish glass, moderately vesicular pumice, and heavy minerals of quartz and feldspar. After crushing in a mortar, the brownish glass looks in color and shape very much like the pale brown shards observed in other samples from this site. The shape of vesicles and degree of vesiculation of the pumice vary. Vesicles are circular to elongate in cross sections. When the pumice is crushed into powder, it is reduced to an aggregate of clear, angular glass shards. Only the pumice with the most elongate vesicles when crushed produces a small proportion of glass with pipe vesicles.

Several fragments of other lithologies were recovered in the cores, including vitric nannofossil ooze (Core 10, Section 2; Core 6,CC) and vitric silty tuff (Core 8,CC).

Unit III: Vitric mudstone and tuff, early Pleistocene; Core 11 (CC), 104 meters sub-bottom.

Two pieces of pale olive sediment with a total length of $9 \mathrm{~cm}$ were recovered from this unit. The lower fragment consists of graded bedded tuff overlain by laminated and cross-laminated vitric mudstone. The upper piece is burrowed vitric mudstone, with the burrows filled with vitric nannofossil chalk.

These lithologies resemble the graded bedded sequences from the early Pliocene at Site 453 and the early Pleistocene at Site 454. The unit is semilithified, contrasting with the soft unlithified fragments of finer sediments recovered from Unit II.

\section{BIOSTRATIGRAPHY}

\section{Summary}

The sediments penetrated at Site 455 before the hole was abandoned due to caving sands, can be dated throughout the sequence by the use of calcareous nannofossils and by radiolarians in the upper part. The oldest sediment encountered in this hole can be referred to the early Pleistocene Emiliania annula nannofossil Subzone. 


\section{Nannofossils}

All of the samples examined from Hole 455 contain nannofossils; however, Samples 3,CC, 5,CC, 6,CC, and $7, \mathrm{CC}$ are coarse-grained sands. Analytical residues of these coarse-grained samples were prepared by washing a portion of the sand in water and examining the resulting wash water. The nannofossils seen in these preparations may be indigenous or may have originated from softer sediments reworked into the sands or even from the drill-string water column. The samples from Cores $1,2,9,10$, and 11 are muds and presumed to be in place. The Holocene-late Pleistocene Emiliania huxleyi Zone can be recognized in Samples 1-1, 90-91 cm and $1-3,90-91 \mathrm{~cm}$. The late Pleistocene Ceratolithus cristatus Subzone of the Gephyrocapsa oceanica Zone can be recognized from Sample 1-5, 90-91 cm to Sample 2-4, 94-95 cm. The Emiliania ovata Subzone of the $G$. oceanica Zone is recognized in Samples 2-6, 90-91 cm through 9,CC. The early Pleistocene Gephyrocapsa caribbeanica Subzone of the Crenalithus doronicoides Zone is recognized in Sample 10-2, 136-137 cm. The early Pleistocene Emiliania annula Subzone of the $C$. doronicoides Zone is recognized in Sample 11,CC.

\section{Radiolarians}

Radiolarians are well represented in Cores 1,2 , and 3. They are present in Cores $4,6,8$, and 9 , but no agediagnostic forms are recognizable. In Cores 5 and 7 (CC), the radiolarian size fraction was too sparse to warrant examination. Core 10 and 11 are barren.

The Buccinosphaera invaginata Zone is represented in Cores 1 and 2, and the Collosphaera tuberosa Zone is present in the lower part of Core 2.

\section{Foraminifers (V. A. Krasheninnikov)}

Only rare Quaternary impoverished foraminiferal assemblages were recovered at Site 455 . Samples 1-1, $50-52 \mathrm{~cm}$ and $1-2,50-52 \mathrm{~cm}$ can be assigned to the late Quaternary Globigerina calida calida Subzone. Samples $1-3,50-52 \mathrm{~cm}$ through $3-2,50-52 \mathrm{~cm}$ can be placed in the undifferentiated Quaternary.

\section{ACCUMULATION RATES}

The accumulation curve (Fig. 5) has been calculated as kilograms of water-free sediment per square centimeter by the method outlined for Site 453 without averaging. The time lines are based on the nannofossil zone boundaries.

The sequence can be divided into three segments with differing accumulation rates.

\begin{tabular}{ccc}
\hline & $\begin{array}{c}\text { Depth } \\
\text { below } \\
\text { Sea Floor } \\
(\mathrm{m})\end{array}$ & $\begin{array}{c}\text { Accumulation } \\
\text { Rate } \\
\left(\mathrm{kg} / \mathrm{cm}^{2} / \mathrm{m} . \mathrm{y} .\right)\end{array}$ \\
\hline 1) $\begin{array}{c}\text { Holocenterval } \\
\text { latest } \\
\text { Pleistocene } \\
\text { (0-0.2 m.y. })\end{array}$ & $0-5.4$ & 3.0 \\
2) $\begin{array}{l}\text { Late } \\
\text { Pleistocene } \\
\text { (0.2-0.9 m.y.) }\end{array}$ & $5.4-81.8$ & 13.0 \\
3) Early \\
$\begin{array}{l}\text { Pleistocene } \\
(0.9-1.6 \mathrm{~m} . \mathrm{y} .)\end{array}$ & $81.8-91.3$ & 2.4 \\
\hline
\end{tabular}

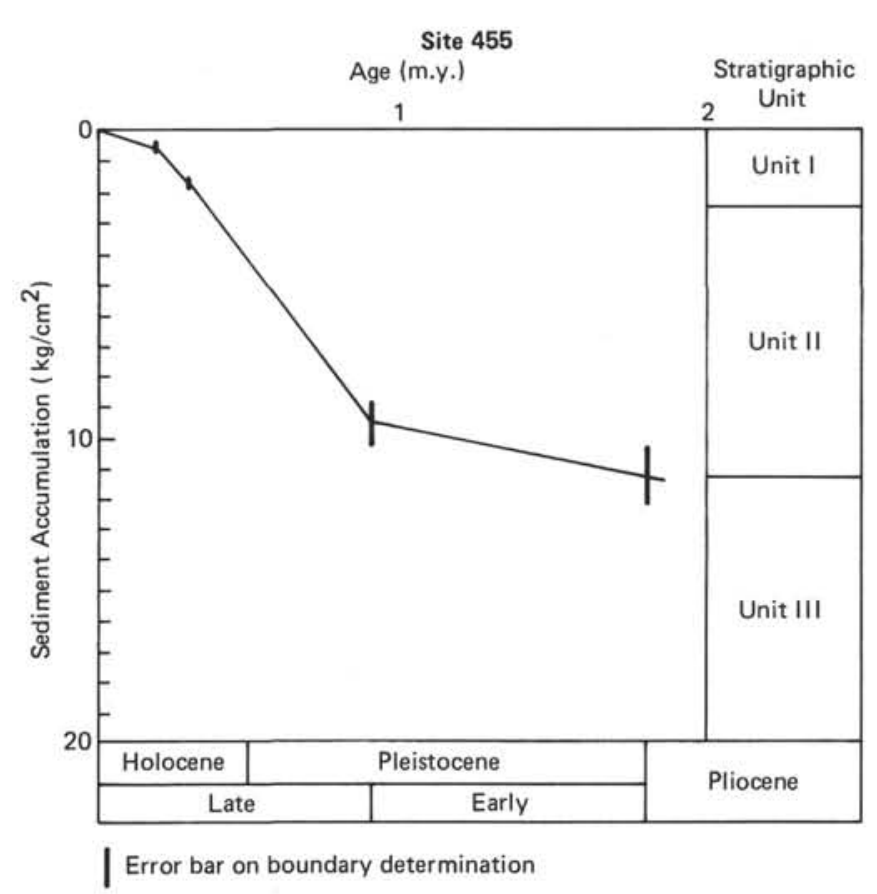

Figure 5. Sediment accumulation rate curves (thickness accumulated versus age), for Site 455. Ages are based on nannofossil zones and subzones (Ellis, this volume).

The accumulation rate for Segment 1 is much lower than that for Segment 2. The decrease in sedimentation rate may be attributable to a decline in volcanic activity. Unlike the two previous sites, Site 455 lies on the same side of the Mariana Trough spreading center as the volcanic arc. Thus the arc-site distance has remained constant after the formation of the sea floor. Changes in sedimentation rates are attributable to changes in the rate of supply of sediment as a result of either changes in the level of volcanic activity or the mode of deposition.

Similarly, the lower rate of deposition in Segment 3 must be attributable to either changes in volcanic activity or mode of deposition, or both. The evidence for a change in style of sedimentation is found in the last material recovered. Segment 3 has the bedding characteristics of the turbidite sequences encountered at Sites 453 and 454 , and may be part of a sequence of beds laid down in the same way as redistributed ash falls. The more rapidly deposited sediments above them could be grain flow deposits forming part of the clastic apron prograding out from the active arc.

However, there is also evidence that the low sedimentation rate in Segment 3 results from a decrease of arc volcanic activity at this time. The rate of sedimentation is also lower at this time at Site 456 , which is located in a pond on a ridge, hence the sediment deposited fell through the water column.

\section{GEOCHEMISTRY}

One sample was squeezed for pore waters at Site 455 (Gieskes, this volume). The sample very nearly resembles sea water in composition, and in that respect is similar to mudline samples from Sites 452 through 454 . 


\section{IGNEOUS AND METAMORPHIC ROCKS}

Apart from gritty material in the sediments, the only igneous materials recovered at Site 455 were coarse sands from Cores 3 to 11 . These consist primarily of angular basalt grains, bits of basalt-glass, and pumice fragments which were severely disturbed by drilling (the pumice, in fact, floated to the top of the coarse sands of several cores, and other types of hydraulic sorting induced by drilling also occurred). The likely source of these sands is nearby Pagan and Alamagan Islands. Because of the disturbed heterogeneous nature of the sands, no systematic visual or petrographic observations were made, although samples were taken for microprobe and geochemical work.

\section{PHYSICAL PROPERTIES}

Compressional wave velocity, wet-bulk density, saltcorrected water content, porosity, acoustic impedance, and thermal conductivity were determined for only the first three cores at Site 455 . Velocity-density parameters are tabulated in Table 2. Below the first three cores coarse sand and gravel were recovered, for which physical property determinations were impracticable. Thermal conductivity data are reported in Horai (this volume).

\section{SUMMARY AND CONCLUSIONS}

Site 455 is on a positive magnetic anomaly that is inferred to be the second normal event (between Anomalies $2^{\prime}$ and 3) within the Gilbert reversed epoch (about 4 m.y. ago) on the magnetic profile of the Glomar Challenger en route to the site. This inferred magnetic age would provide an average half-spreading rate of about $1.3 \mathrm{~cm} / \mathrm{y}$. for the eastern half of the Mariana Trough. Sediment thickness assessed from the site surveys and the Glomar Challenger air-gun profile in the general vicinity of Site 455 is more than $1 \mathrm{~km}$, but at the site chosen the sediment thickness is interpreted to be only slightly over 300 meters.

No basement was cored at the site. The sediments penetrated and cored were all Pleistocene in age and can be classified into three units:

Unit I $(0-22 \mathrm{~m})$ is late Pleistocene vitric mud, vitric nannofossil ooze, and vitric silty to sandy ash. Volcanic glass, commonly pale brown, is abundant. In Core 3, clear glass with a low refraction index is also present.

Unit II $(22-95 \mathrm{~m})$ consists mainly of early to late Pleistocene, volcanic sand and gravel with minor occurrences of nannofossil mud and silty tuff, all highly disturbed by drilling. The volcaniclastic materials are angular basalt grains, bits of basalt glass, and pumice fragments, probably from nearby Pagan and Alamagan Islands.

Unit III (96-104 m) is represented by two pieces of pale olive sediments, with a total length of $9 \mathrm{~cm}$. The upper piece is borrowed vitric mudstone and the lower graded bedded tuff overlain by laminated and crosslaminated vitric mudstone. These lithologies resemble the turbidite sequences from the early Pliocene at Site 453 and the early Pleistocene at Site 454.

The oldest sediment at Site 455 can be referred to the early Pleistocene Emiliania annula Subzone.

Estimates of accumulation rates at Site 455 are uncertain because of poor biostratigraphic control, but appear to range from $2.4 \mathrm{~kg} / \mathrm{cm}^{2} / \mathrm{m}$.y. in the early Pleistocene to $13 \mathrm{~kg} / \mathrm{cm}^{2} / \mathrm{m}$.y. for the most of the late Pleistocene.

The lithologies at Site 455 generally resemble those at Sites 453 and 454 in that the uppermost layers are slowly deposited nannofossil ooze and the lower sections contain turbidites (early Pliocene at Site 453 and early Pleistocene at Site 454). The occurrence of coarse volcanic sands and gravels is the only major distinction of Site 455 .

Site 455 did not achieve the stated objectives of the drilling, so an alternate nearby site, also within the SP4D survey region, was drilled (Site 456/Hole 456A) in an attempt to meet these objectives.

Table 2. Physical properties measurements, Site 455.

\begin{tabular}{|c|c|c|c|c|c|c|c|}
\hline $\begin{array}{c}\text { Sample } \\
\text { (Interval in } \mathrm{cm} \text { ) }\end{array}$ & $\begin{array}{c}\text { Sound } \\
\text { Velocity } \\
\text { (vertical) } \\
(\mathrm{km} / \mathrm{s})\end{array}$ & $\begin{array}{c}\text { GRAPE } \\
\text { 2-minute } \\
\text { Wet-Bulk } \\
\text { Density } \\
\left(\mathrm{g} / \mathrm{cm}^{3}\right)\end{array}$ & $\begin{array}{c}\text { Water } \\
\text { Content } \\
\text { (salt- } \\
\text { corrected) } \\
(\%)\end{array}$ & $\begin{array}{c}\text { Porositya } \\
(\%)\end{array}$ & $\begin{array}{c}\text { Wet-Bulk } \\
\text { Density } \\
\left(\mathrm{g} / \mathrm{cm}^{3}\right)\end{array}$ & $\begin{array}{c}\text { Acoustic } \\
\text { lmpedance } \\
\left(\mathrm{g} / \mathrm{cm}^{2} \mathrm{~s} \times 10^{5}\right)\end{array}$ & Rock Type \\
\hline $1-3,100-102$ & 1.58 & & & & & & Very disturbed \\
\hline $1-4,21-23$ & 1.57 & & 40.9 & 65.1 & 1.63 & 2.56 & Very disturbed \\
\hline $1-5,87-89$ & 1.57 & & & & & & Sandy mud \\
\hline $1-6,68-70$ & 1.61 & & 36.5 & 60.9 & 1.71 & 2.75 & Sandy mud \\
\hline $2-1,103-105$ & 1.53 & 1.61 & & & & 2.46 & Ooze \\
\hline $2-3,61-63$ & 1.52 & 1.71 & & & & 2.60 & Ooze \\
\hline $2-4,20-22$ & 1.55 & 1.73 & 37.2 & 62.0 & 1.70 & 2.64 & Firm mud \\
\hline $2-6,127-129$ & 1.58 & 1.83 & & & & 2.89 & Stiff clay \\
\hline $3-2,76-78$ & 1.59 & 1.74 & 34.7 & 59.0 & 1.74 & 2.77 & Firm mud \\
\hline
\end{tabular}

a Porosity $=$ salt-corrected content $\times$ wet-bulk density (gravimetric)/1.025.

b Gravimetric method. 

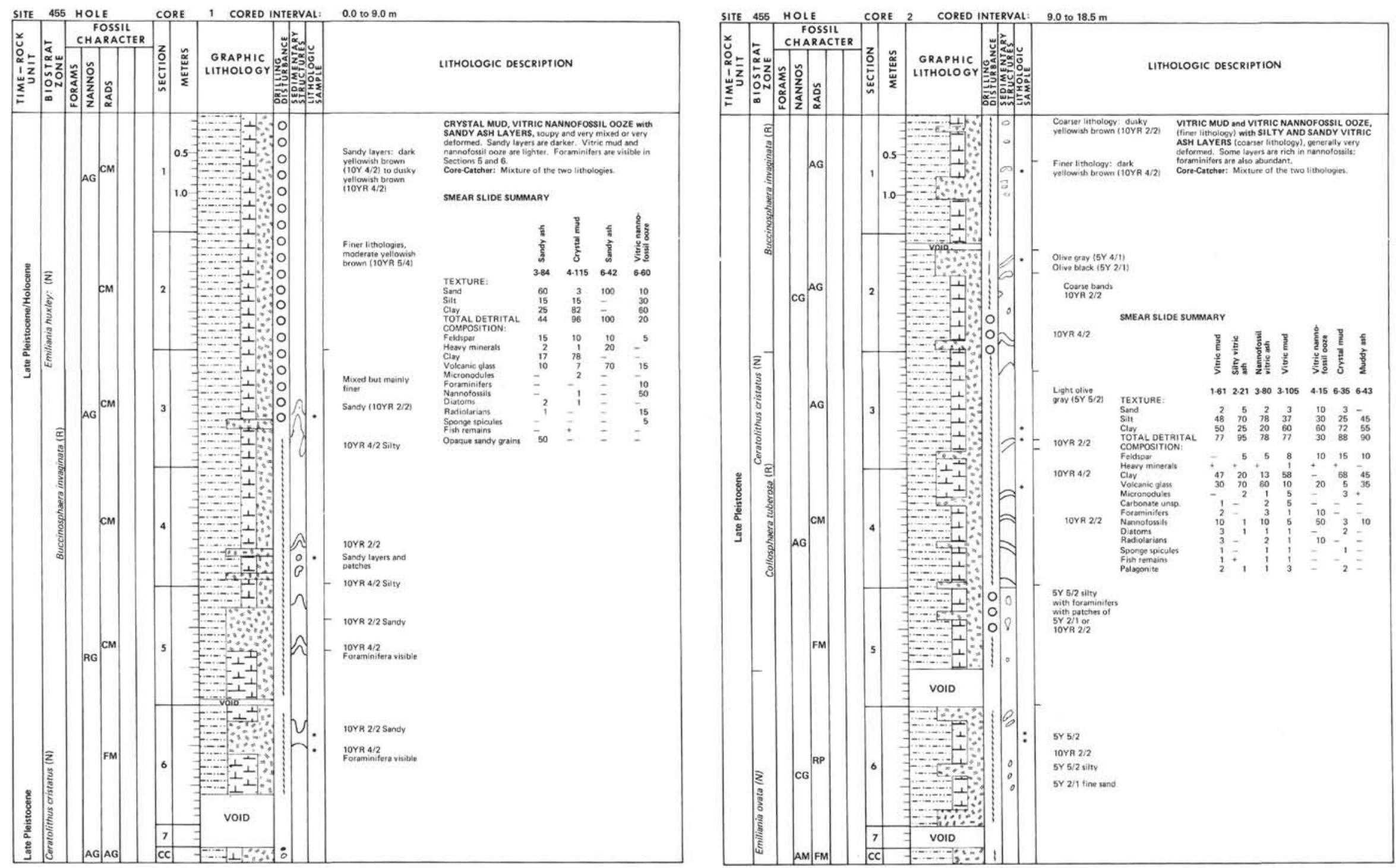


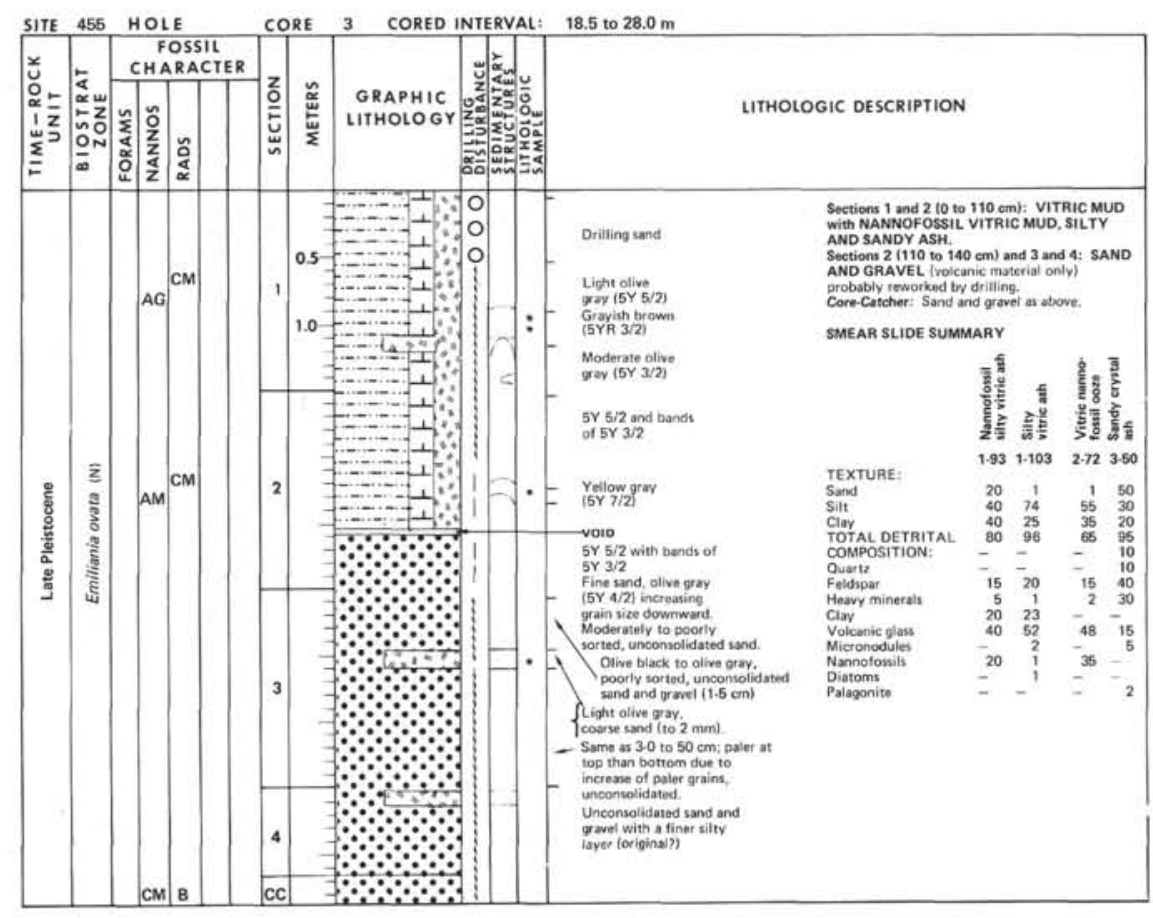

\begin{tabular}{|c|c|c|c|c|c|c|c|}
\hline IIE & & HOL & & $\mathrm{cor}$ & & 4 CORED INTERVAL: & 28.0 to $37.5 \mathrm{~m}$ \\
\hline & & $\mathrm{FC}$ & $\begin{array}{l}\text { OSSIL } \\
\text { ORACTER }\end{array}$ & & & & \\
\hline 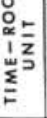 & 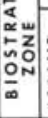 & 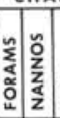 & \begin{tabular}{|l} 
\\
0 \\
0 \\
$\alpha$ \\
$\alpha$
\end{tabular} & 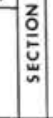 & 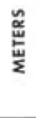 & 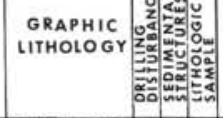 & LITHOLOGIC DESCRIPTION \\
\hline & & & RM & cc & & $\because \because \because \because \because \because \because 0$ & $\begin{array}{l}\text { Corte-Catcher: VOLCANIC SAND AND GAAVEL, roworked by } \\
\text { driling }\end{array}$ \\
\hline
\end{tabular}

SITE 455 HOLE CORE 5 CORED INTERVAL: 37.5 to $47.0 \mathrm{~m}$

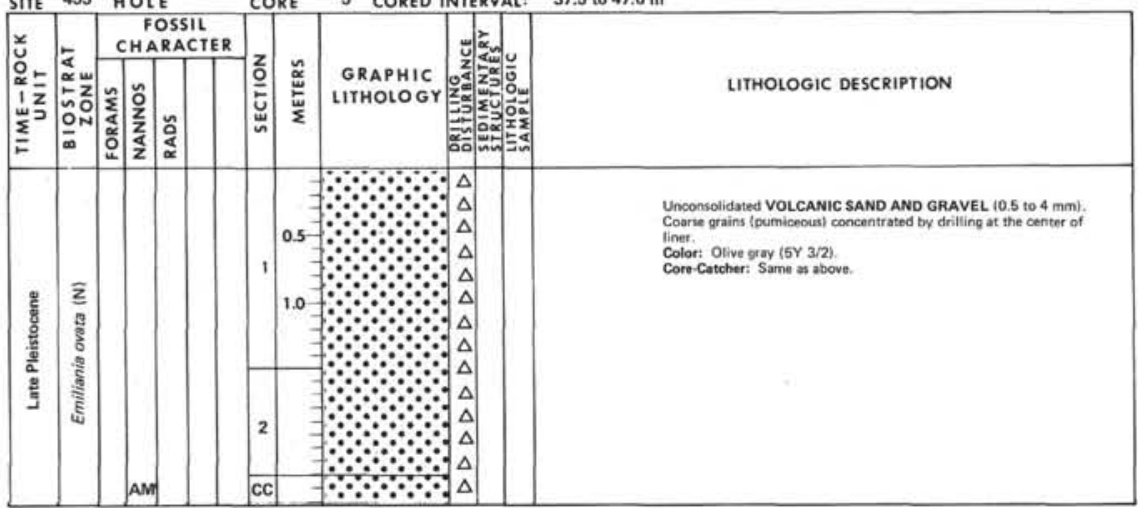

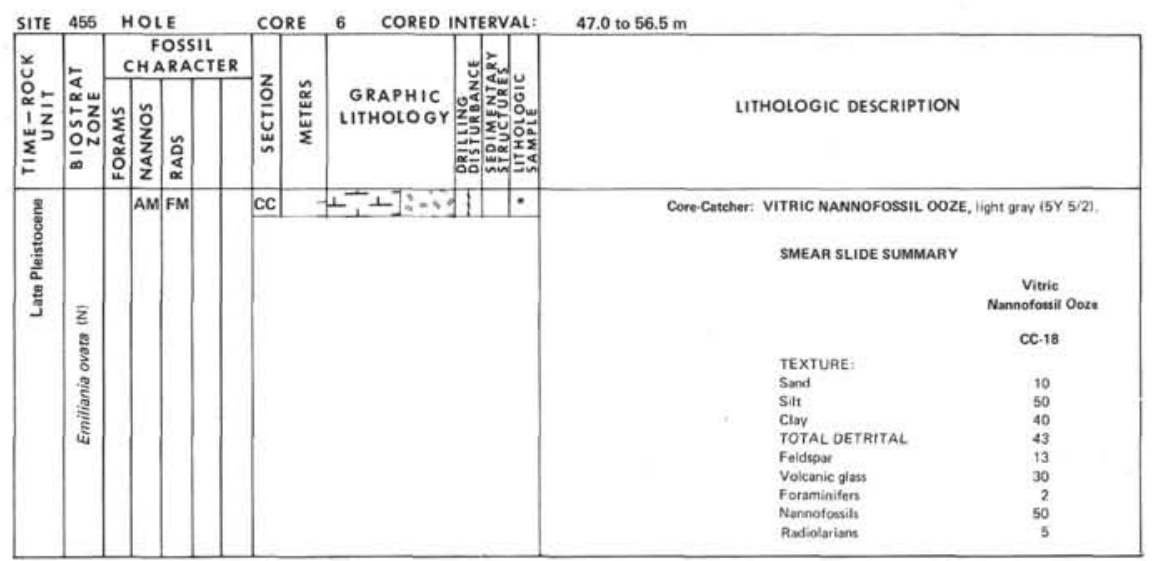

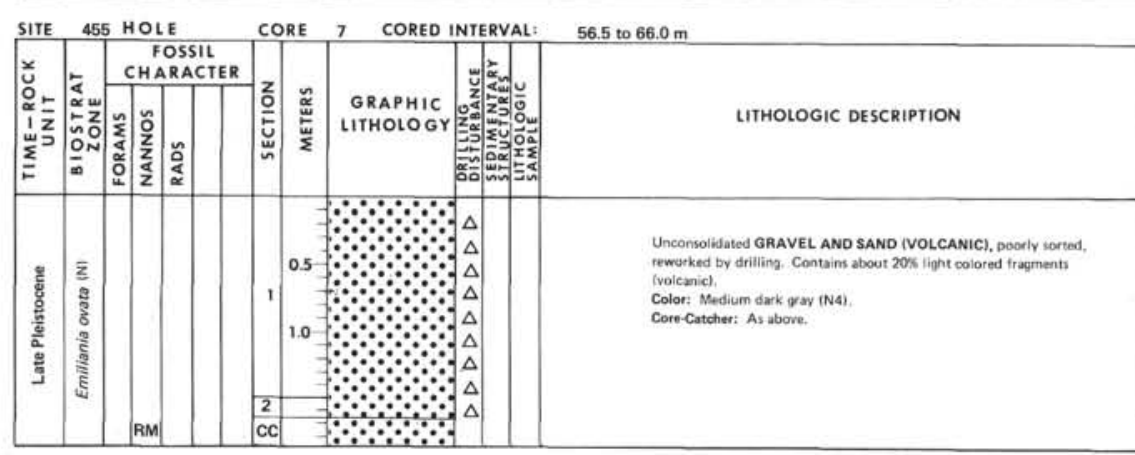

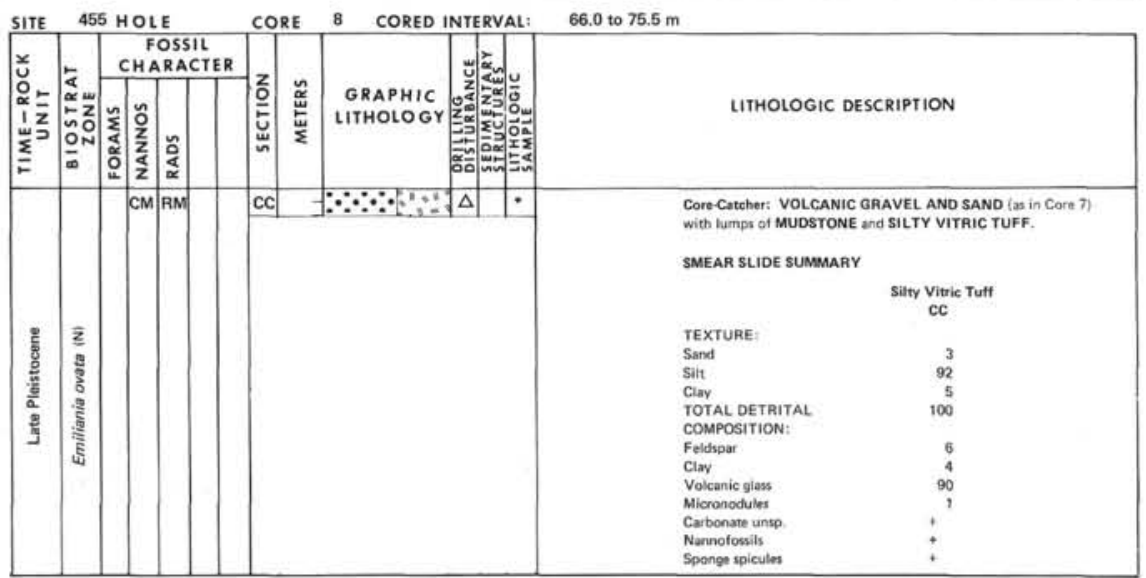




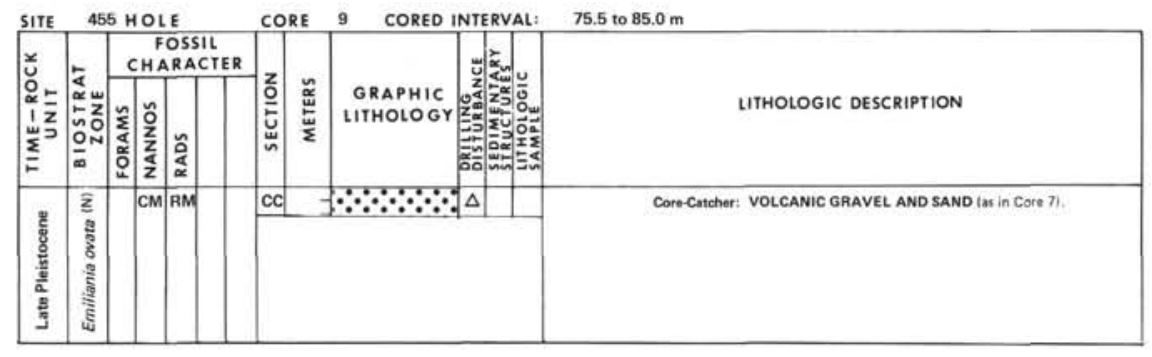

SITE 455 HOLE CORE 10 CORED INTERVAL: 85.0 to $94.5 \mathrm{~m}$

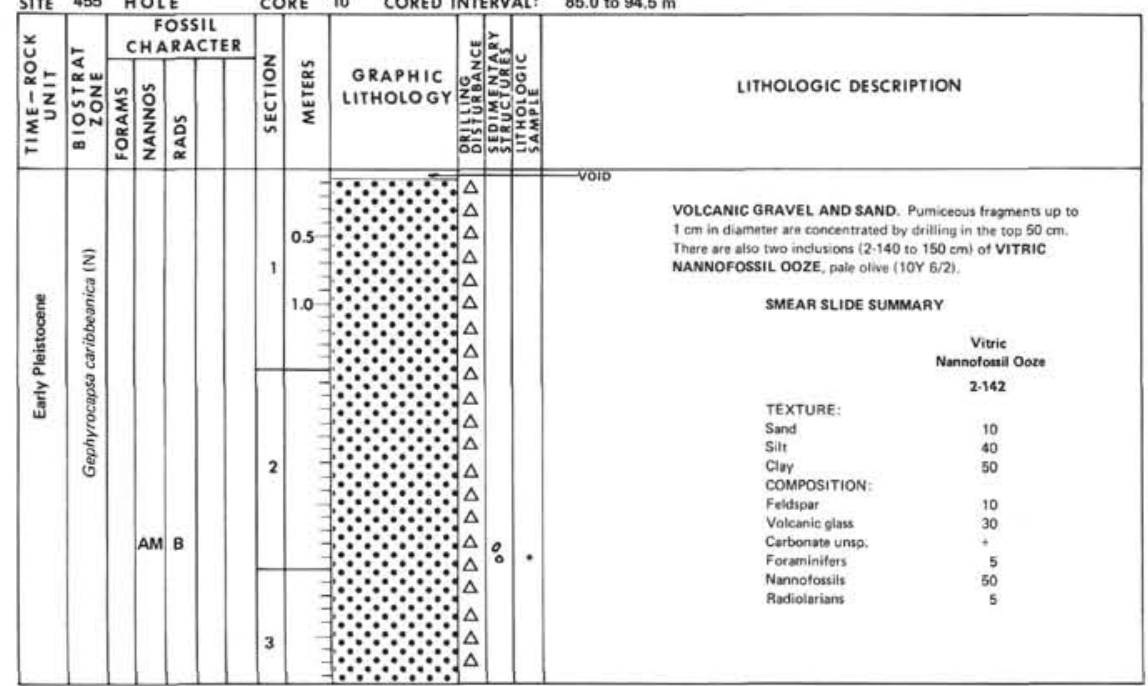

\begin{tabular}{|l|l|l|l|l|l|l|l|l|l|}
\hline SITE & 455 & HOLE & & \\
\hline
\end{tabular}


Site 455

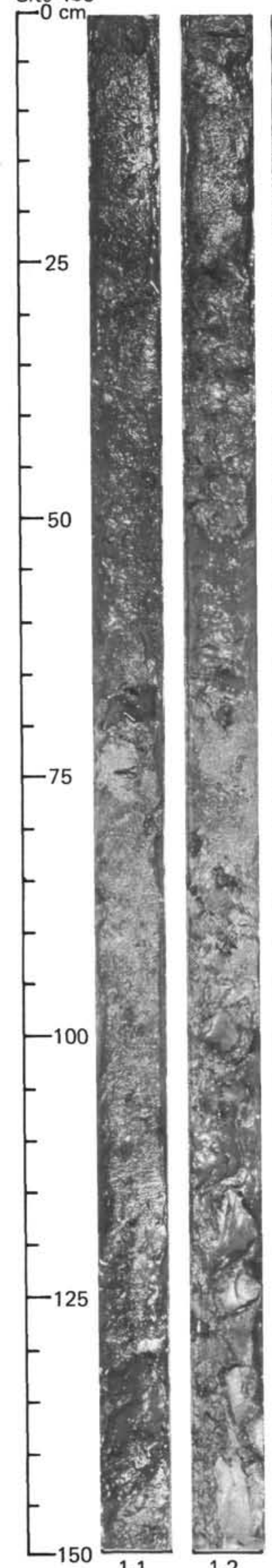

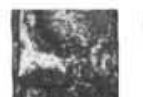
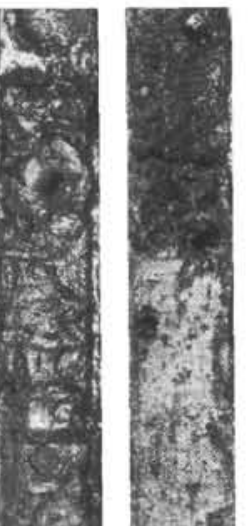

1. 21

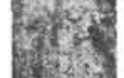

(1)
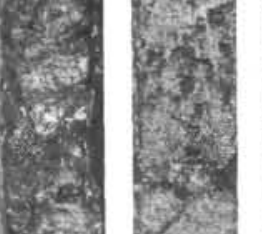

Lisis
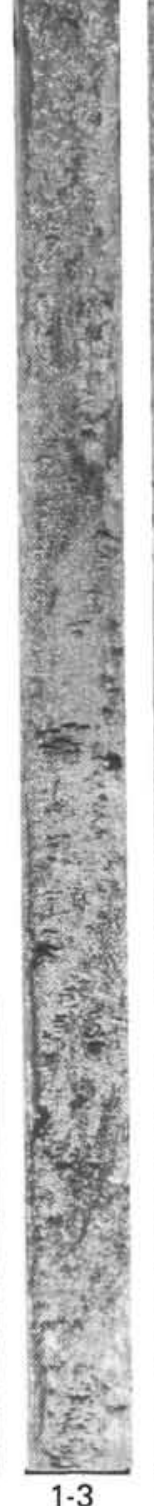
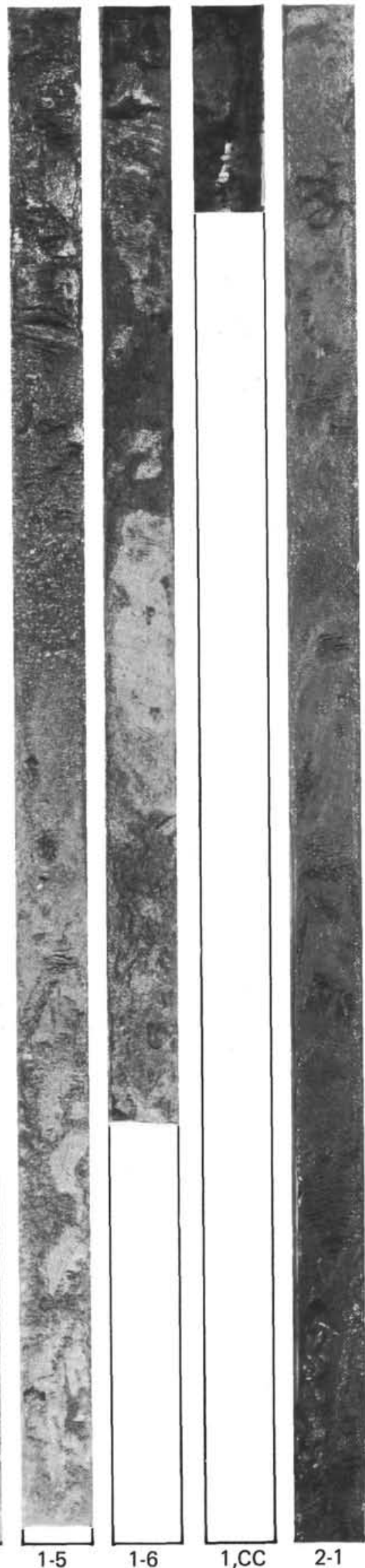
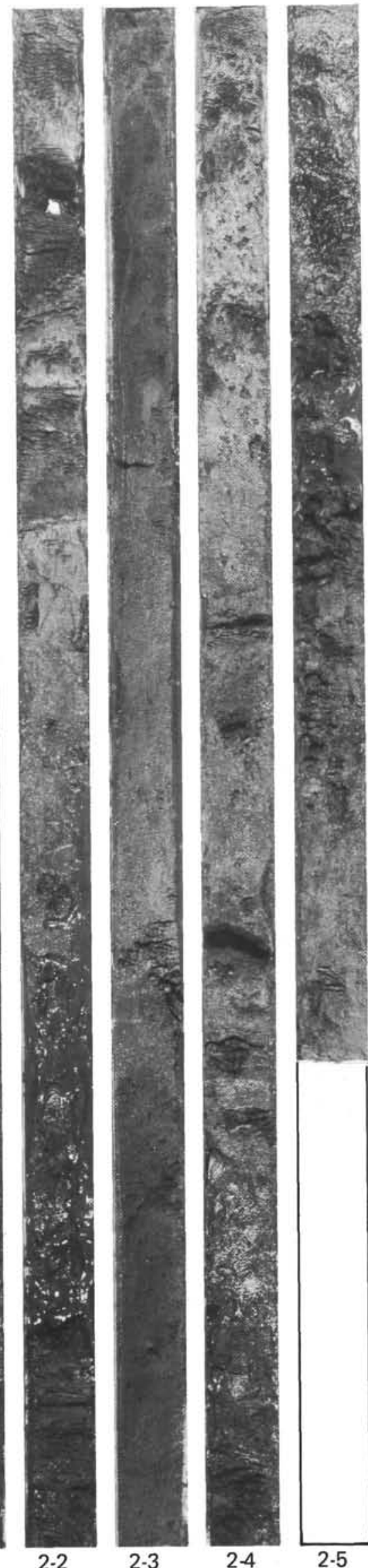
SITE 455

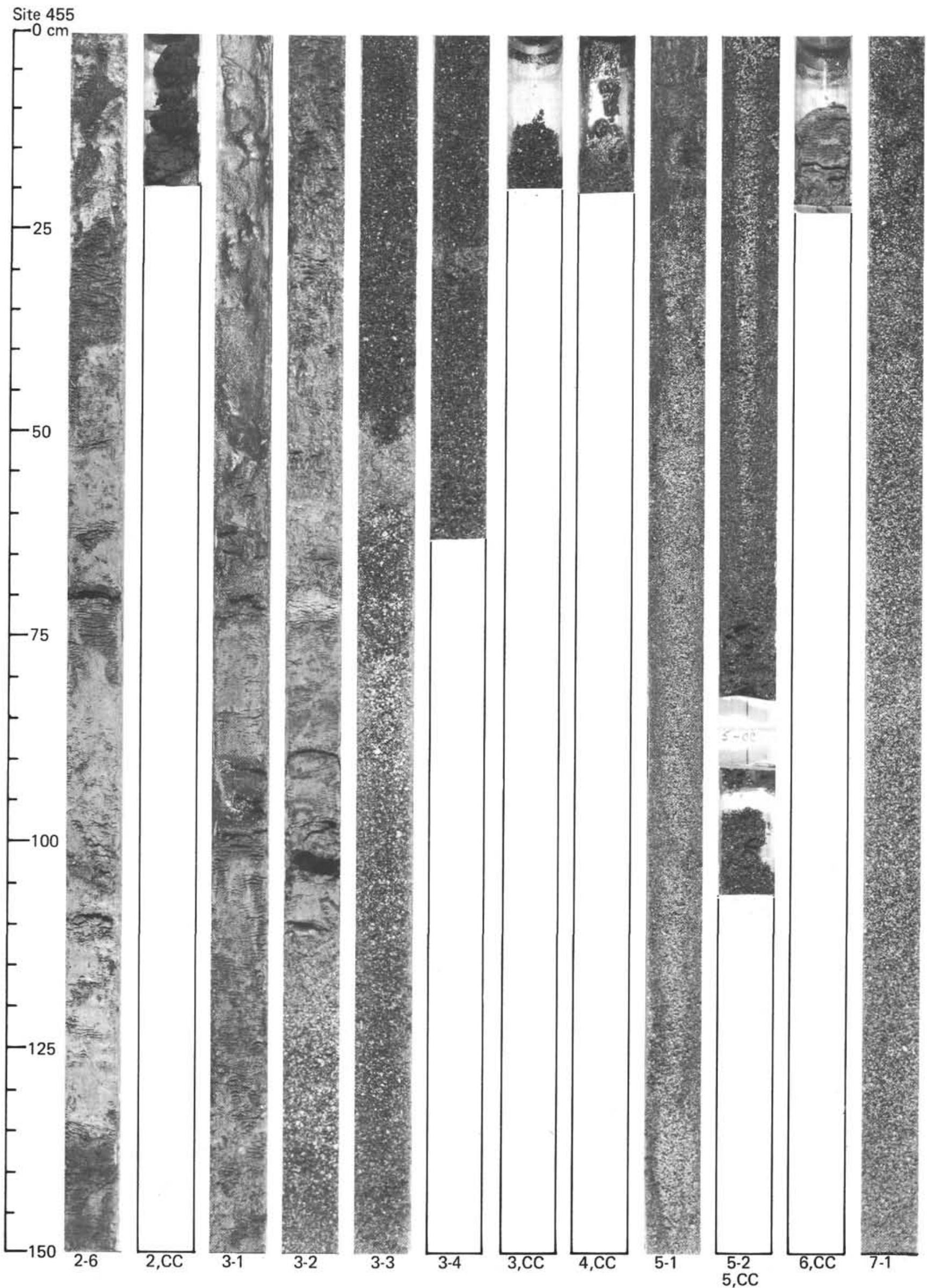




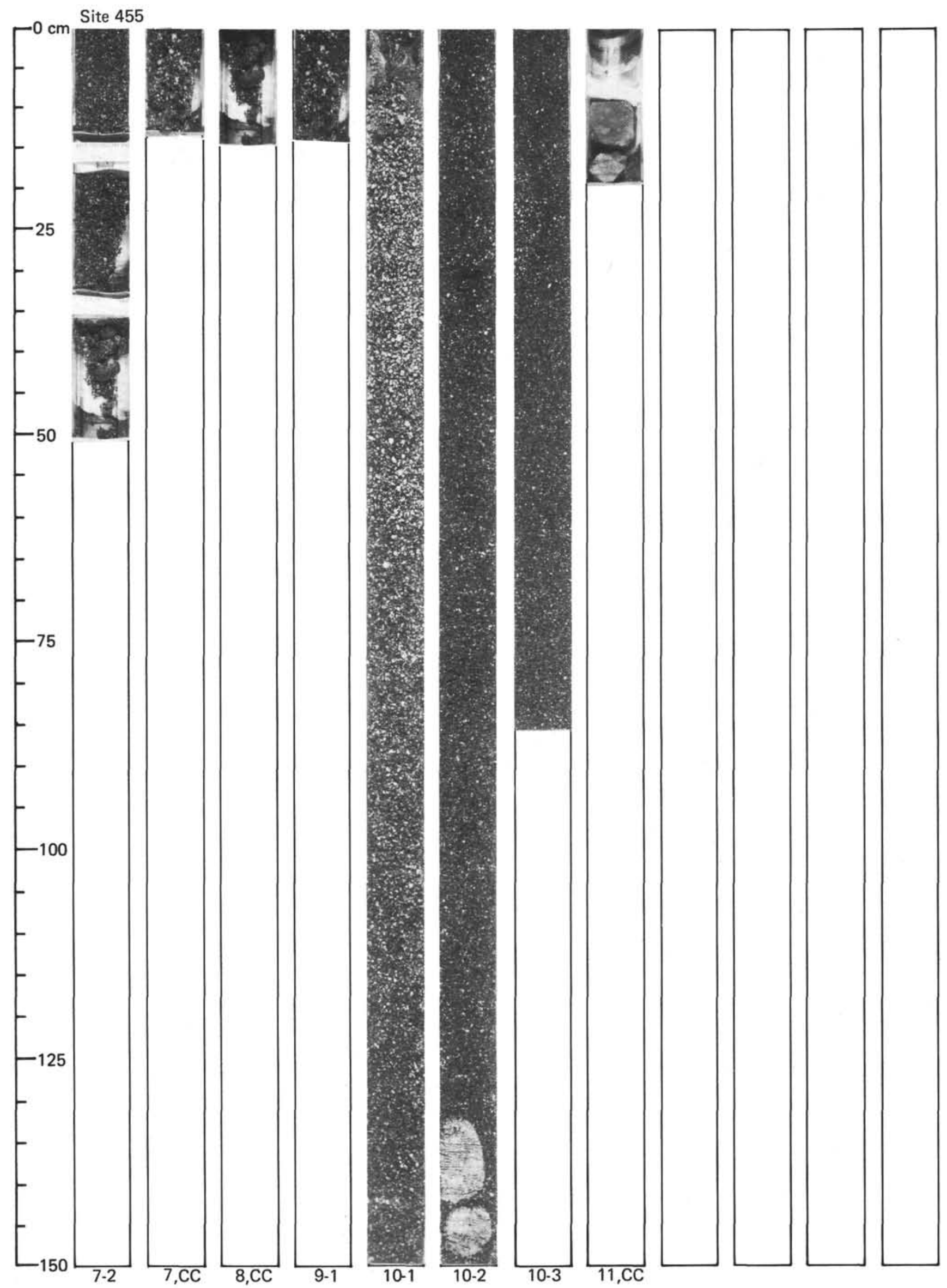

